\title{
College and University Archives: the Experience of One Institution
}

The organization and administration of the records of institutions of higher education is a field which is attracting increasing attention of college and university librarians, partly because of the parallel growth of interest by professional historians in the area of American educational history. This article discusses the author's experiences in organizing the archives of Tufts University preparatory to writing its history. A Statement of Archival Policy adopted by the Tufts trustees is appended, which might provide practical guidance for other institutions.

$\mathrm{U}$ NTIL COMPARATIVELY RECENTLY, the organization, administration, and maintenance of the records of institutions of higher education have not been major concerns of most colleges and universities or of their librarians. What materials do exist are, more likely than not, locked away in the office of the trustees, stuffed in a closet of the administration building, or relegated to a dusty corner of the library where they are disturbed only when (1) spring housecleaning (or moving) time rolls around, or (2) an alumnus of the class of 1907 writes in to make sure that the "beanie" he wore as a freshman and proudly presented to his alma mater on the occasion of his thirty-fifth reunion is still intact. What archives do exist have occasionally, in the past at least, been but imperfectly exploited by a retired graduate who has determined to devote his declining years (and failing memory) to producing a series of filiopietistic anecdotes in which his alma mater will take delight

Dr. Miller is Professor of History, Historian, and Archivist at Tufts University, Medford, Massachusetts. The substance of the present article was presented at Tufts in March 1966, at a meeting of New England College Librarians. and which will (possibly fortunately) reach only a limited audience of fellow alumni. More and more frequently in recent years, however, it has been the professionally trained historian who has disturbed the tranquility of the archives (or of their custodians), in quest of the primary documents indispensable for scholarly research and publication. Institutional histories reflecting not only sound and thorough scholarship but representing significant contributions to the growing and maturing fields of American social and intellectual history have come off the presses in increasing numbers in the past few decades. By a rough estimate, about one-third of the more than fifteen hundred degree-granting institutions of higher learning in the United States have a written history of some sort. A significantly lessening proportion are concerned largely with student pranks, athletic victories, absentminded professors, or the Old School Tie in general.

It is gratifying and encouraging to see growing interest not only in scholarly institutional history but in increasing attention paid by librarians to archival matters. Indicative of this trend was the choice of the topic "University Archives" 
for the Eleventh Allerton Park Institute, sponsored by the faculty of the graduate school of library science of the University of Illinois in the fall of $1964 .^{1}$ This writer, who was fortunate to have been able to attend the conference, returned from the stimulating and informative meetings and accompanying shop talk with a set of tentative conclusions. It seemed clear that there was no one set of "ground rules" that would apply to all college or university situations. It seemed safe to conclude, also, that there was no uniformity as to the size, importance, or condition of the collections; they range from the most systematic and elaborate to literally nothing at all. The consensus was that scientific archival management, so far as it applied to institutional materials, was either in its infancy or has been sadly neglected by both librarians and teachers of library science-and that something should be done about it, although no one seemed to have the ideal blueprint at hand.

The discussion that follows is in no sense offered as a solution to all of the problems raised at the meeting in 1964. Even less can the following be considered a model for other institutions. Yet at the same time, it is to be hoped that a brief report of the experience of one relatively small university might be instructive to those who contemplate the establishment of a collection, no matter how modest.

It is suggested that at least five ingredients are necessary to a successful archival operation. First, there must be something archival to gather, preserve, and make usable by someone else. This presupposes, in turn, some person (or persons) sufficiently interested in and aware of the potential or actual value of archival materials to do something about it. No matter how young or small the

\footnotetext{
1 All but one of the papers presented at this conference, held November 1-4, were published in a booklet in 1965 . The collection was edited by Rolland E. Stevens and was distributed by the Illini Union Bookstore, Champaign, Illinois.
}

institution, there is, by the very nature of the establishment, at least a small corpus of relevant materials-if nothing more than a few battered catalogs and some aging faculty minutes. As to the personnel, the institution's librarian, or at least a member of his staff, is almost invariably involved, willingly or not. Ordinarily, although not always, one or more members of the department of history are interested, or can be interested, in the archives of the institution.

A second indispensable is some kind of a workable definition of what is properly archival. Here some of the most basic and knotty questions arise, and sweeping generalizations become misleading if not downright dangerous. College or university collections, it must be remembered, are distinct from public or state archives, which pose their own problems of housing, classification, financial support, preservation, and access. It should also be noted that the term "archives," whether public or private, should be broadly construed. They are not just serried rows of government documents, or anything not current, or items in manuscript form only. Institutional archives comprise those records and other evidences, written or pictorial, no matter what their physical form (or condition), which are associated with the history of a particular educational entity per se. This, in turn, raises a multitude of related questions. Should all existing written efforts of faculty and alumni, scholarly or otherwise, be included? Are what is usually called "memorabilia" properly archival, or should archives double as museums? On many college campuses, there are from a few to hundreds of art objects (some of which ought probably never to have seen the light of day), ranging from decrepit portraits of assorted Founding Fathers down to shovels used for ground-breaking exercises for a new gymnasium or for burying for future ages the records of the class of 1884 . Most people agree that 
such items should be kept-but by whom? "Let George do it" frequently turns out to be the reluctant librarian.

Granted the existence of archival material, and some initial decision as to inclusion (and exclusion), the collection must be sufficiently well organized and accessible to be of some value to someone besides the archivist. Even though the bulk of the materials will never rival those in the national archives, and may never be used outside college walls, they must be usable. This means the establishment of a coherent and logical filing system and the creation of such reference aids (for example, indexes or card catalogs) as will make for both simplicity and utility.

Indispensable to a successful archival arrangement is a set of institutional officers sufficiently educated to and sympathetic with the whole concept to assure more than moral support. This means provision for both an administrative and physical home for the archives, plus some financial assistance and any other tangible evidence of good will-including provision of clerical assistance. Equally vital to archival success is a satisfactory working relationship between the archival office and the library, and particularly the librarian. This relationship must be based on a coherent and mutually satisfactory chain of command, preferably committed to paper, yet flexible enough to allow for actions and decisions not anticipated but often quite necessary.

Finally, a rationale or justification, philosophical or otherwise, is needed for the very existence of archives. It is for this reason that mention was made earlier of the need to educate people sufficiently-particularly administrators-to their value, to make them do something about archives. Certainly current support continues to be forthcoming from the field of historical scholarship and the intensified interest in the history of higher education.
Moving from generalities to specifics, the remainder of this discussion is devoted to the archival experience at Tufts University. This case study of one institution probably reveals as typical a situation as can be found in an area that is still suffering from growing pains, and that has made a late and rather sporadic appearance on the academic scene. Two of the five indispensable ingredients mentioned above were present at Tufts at the outset: the whole development had the wholehearted cooperation and support of the administration and trustees, from an open-ended special account against which to charge necessary expenses when the project was begun, to continued financial support and encouragement after the archives became a reality; and an exceptionally harmonious relationship existed between the archival office and the university library staff, and particularly the librarian. When spacious quarters for the archives were provided in the new university library opened in September 1965, the archivist was consulted in both the preliminary and final planning.

The archives as presently constituted were born out of the suggestion of the writer who, as a "card-carrying" historian with an interest in American educational history, became eligible for a sabbatical leave and simultaneously became convinced that a comprehensive, scholarly history of the institution was a desideratum. The president received the suggestion enthusiastically, and assured the writer access to anything that might be needed. This immediately raised a question: Where was the raw material out of which such a history could be constructed, and how much was available? It was soon discovered that there was no such thing as an archival collection, but fortunately there was a senior member of the library staff (and an alumna) who collected items relevant to the institution as an extracurricular activity and answered questions about it as best she 
could. There were also unearthed in the administration building complete sets of faculty and trustee minutes and various supporting documents. It was rapidly realized also that no New Englander ever threw anything away; the erstwhile author soon discovered that he had too much rather than too little with which to work. Consequently, approximately three years (beginning in 1958-59) were spent in collecting archival materials, setting up a filing system, and providing a locator index which turned out to be one of the most frequently used parts of the archives. In the meantime, the writer, much sobered by the magnitude of the task he had inadvertently set for himself, had long since returned to his regular academic duties, although some readjustment was made in his teaching load to enable him to carry on his new activities.

Certain features of this largely bootstrap operation illustrate the typology of institutional archives. It had been discovered that no systematic attempt had been made to establish archives for an institution entering its second century (it had been chartered in 1852); much of what material had been collected had been preserved largely through the efforts of a loyal graduate of the school as a self-appointed assignment; the organization of the archives, when it was begun, was the outgrowth or by-product of another project; and the so-called archivist, with no technical or professional training in the field, was serving in a strictly ad hoc, part-time capacity. The trustees, after due deliberation, and on the initiative of the university librarian, officially recognized the existence of the archives in February 1964, and effective in September 1965-a month before the manuscript of the history of the institution was completed-created the post of university historian and archivist.

One of the great merits of the arrangement as worked out was that the writer of the history was simultaneously the organizer of the archives, and there- fore was in the best possible position to know what resources existed and where they were to be found. Another advantage was the establishment as soon as practicable of formal machinery and relationships between the library and the archives housed in it. The first step was the creation (again at the suggestion of the university librarian) of a university archives committee, established by the president early in 1962 . After a series of informal meetings a preliminary determination was made of what was to constitute archival materials. Fourteen categories were eventually established, with appropriate subdivisions. For preservation and safe-keeping, budgetary provision was made for the microfilming of selected major records, to be updated at two-year intervals. Appended is the statement of policy on university archives adopted by the Tufts trustees which might be of some interest and, with appropriate adjustments to local circumstances, could conceivably be used elsewhere. It has so far proved a reasonable and workable set of guidelines.

Aside from serving their original purpose-making possible the writing of a history of the first hundred years of the institution-the archives are serving a continuing function. An average of one inquiry a week is being received; about half of them come from outside the school. Two part-time assistants (one paid by the hour and the other devoting half her full-time position on the library staff) very adequately supplement the efforts of the part-time archivist. As would naturally be expected, very few of the dozen or so projects simultaneously under way will ever be completed (e.g., the processing of non-current student records and the indexing of minutes and student publications) but at least a home can usually be found for virtually everything; above all, the materials can be made available to interested and responsible persons.

Much remains to be done, and not all 
problems have been solved. For example, the goal of centralizing all archives in a not-so-large but surprisingly complicated institution (with numerous professional schools) has not been fully achieved; there are the problems of obtaining a measure of uniformity in record-keeping and disposition; and the task of educating the numerous components of the university about the work of the archival office is far from complete. One great step was taken when excellent cooperation was established with the university's alumni records office which houses and services materials concerning any living person associated with the institution.

In a field such as this, it is all too easy to become immersed in routine and details, and to forget the fifth indispensable ingredient of an archival collection mentioned earlier-the rationale behind it. With a certain amount of audacity from a person whose only training in the field has been experience, the writer offers the following considerations. No institution, educational or otherwise, springs full-blown; it is a product of evolution, development, cumulation; it is built on the past. Hence, archives become record depositories of what has happened; they serve the elemental function of preservation for its own sake. Institutional archives also serve as a storehouse of retrievable information for any legitimate purpose-from furnishing biographical data about a deceased alumnus to answering inquiries from within the larger academic community. Finally, the archives of the kind described here may-and do-serve increasingly as a vital resource for scholarly researchers in the ever-widening realm of social and intellectual history. Archives serve not only the present but furnish the grist for posterity.

\section{Policy on Universal Archives ${ }^{\circ}$}

The university regards as matters of official concern the collecting, preserving, and

\footnotetext{
- Adopted by the Executive Committee of the Trus-
} tees of Tufts College, February 13, 1964. organizing of the records, documents and reference sources relevant to its history. The archival and historical repositories that now exist within the University have been developed on the initiative of individuals and as part of the normal office practices of the various departments and divisions. Separately, within their naturally imposed limits, and in the aggregate, these repositories are comprehensive in scope and rich in archival resources. These resources are at the same time occasionally both incomplete and duplicated; there are no adequate assurances for their consistent and continued development and maintenance, and there are no consistent standards being applied for their selection and preservation.

To ensure that all archival materials of importance are retained, adequately housed, and organized for use, the University adopts the archival policies and practices outlined below:

1. An official Archives Collection will be established to serve as the depository of archival and historical materials for all the divisions and departments of the University.

a. The Archives Collection shall be considered a department of the University Library and shall be housed in the main University Library.

b. The University Archivist shall be appointed by the President after consultation with the Archives Committee to maintain, organize, and service the Archives Collection. He shall be a member of the University Library staff and be responsible to the University $\mathrm{Li}$ brarian.

c. If the University Archivist is not a member of the Department of History, a member of the faculty of the Department of History shall serve in an advisory capacity to the University Librarian on matters pertaining to the Archives.

2. Status, duties, and responsibilities of the University Archivist.

a. The position shall be part-time.

b. If a member of the faculty is appointed, his normal academic load will be so adjusted, in consultation with and with the consent of his department chairman, that up to one-third of his time will be devoted to archival activities.

c. The Archivist shall be immediately responsible for the maintaining, organiz- 
ing, and servicing of the University Archives, as a part-time member of the staff of the University Library, ultimately responsible to the University $\mathrm{Li}$ brarian. The Archivist shall also be responsible for answering inquiries and otherwise making available to authorized users the contents of the Archives, in accordance with policies established by the Committee on Archives.

d. Facilities will be provided in the University Library for the use of the Archivist.

e. Part-time secretarial and research assistance for the Archivist will be provided, if necessary.

f. Provision will be made in the University Library budget for secretarial services, supplies and equipment for the Department of Archives which shall be in addition to the present budget of the University Library.

g. The Archivist shall be responsible for making periodic reports to the University Librarian.

h. The University Archivist shall be a member of the Committee on University Archives, ex officio.

3. The Collection will be essentially a non-current collection of the types of materials outlined in paragraph 4 below.

a. For general purposes all copies of any material incorporated in the Collection will be considered archival copies. Technically, copy properly designated as "archival" must be the original document and not a copy, and to the extent possible and desirable it will be the original documents that will be deposited in the Archives Collection. Carbon copies of outging letters will, of course, be included.

4. The following types of materials will be included in the Archives Collection:

a. Minutes and records of the Trustees of Tufts College.

b. Minutes and records of the several facculties and committees of the University.

c. Presidential correspondence.

d. Official reports, periodic and special.

e. Catalogues and bulletins, general and special.

f. Special publications (e.g., Tufts Carne- gie Self-Study, press releases).

g. Non-current student records.

h. Student personnel folders from the files of the Deans and of major departments to be deposited with the Archives under policies and procedures to be determined.

i. Student publications.

j. Records of student organizations and activities.

k. Non-university publications:

1. Newspaper clippings and scrapbooks (on a selective basis).

2. Pamphlets and books dealing wholly or in part with Tufts (to be made available in both the general and the archival collections. If materials exist in only a single copy the required duplicate is to be obtained by photocopying or microfilming).

1. Pictorial materials.

m. Association materials.

1. Theses (both undergraduate and graduate).

2. Publications with the Tufts imprint.

3. Publications of the Alumni Association (Materials issued by Tufts Clubs of the various cities in the country are not to be solicited but will be added if they are offered).

4. Records of organizations associated with the University.

n. Appropriate material from interested alumni.

5. The following categories of material will not be incorporated in the Archival Collection unless their substance relates to the University:

a. Publications by faculty.

b. Publications by alumni.

c. Materials deposited because of a unique association (e.g., the P. T. Barnum Collection).

6. Because of their importance to the archival needs of the University and for reasons associated with their uniqueness, the form in which they were issued, or the quality of paper used, certain categories of archival materials will be microfilmed.

a. The positive copy of the microfilm will be deposited in the Archival Collection and the negative copy will be deposited for security purposes in storage outside the University premises. 
b. The following materials have been initially selected for microfilming:

1. Minutes of the Meetings of the Trustees of Tufts College.

2. Minutes of the Meetings of the Faculties with selected supporting documents (including standing committee reports, of which only one copy is known to exist).

3. The President's Annual Report to the Trustees.

4. The Tufts Weekly (student newspaper).

5. The student literary magazine.

6. Student records (transcripts, etc.).

7. Tufts Self-Study reports and documents.

7. Official records and documents not published or intended for general distribution will be considered confidential and access to them will be limited to designated and authorized individuals.

8. There shall be a standing committee on University Archives appointed by the President, consisting of the University Librarian (Chairman); the Senior Vice President (Provost); the University Recorder; the University Archivist, ex officio; a faculty advisor from the Department of History; and such other members as the President deems necessary. Among its duties shall be (a) the establishment of procedures by which the archival materials listed above are obtained from divisions, departments, and offices; (b) the determination of what other materials (i.e., not listed above) shall be deposited in the Archives; and (c) the establishment of policies governing access to and use of the several categories of archival material.

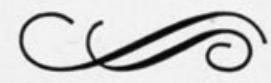

